DOI: $10.20472 /$ IAC.2017.028.010

\author{
CLIFFORD MACHOGU \\ MURANG'A UNIVERSITY OF TECHNOLOGY, KenYa
}

REUBEN YEGON

Kisii University , Kenya

\title{
THE EFFECT OF ECONOMIC DETERMINANTS ON PERFORMANCE OF DAIRY COOPERATIVE SOCIETIES IN KERICHO COUNTY
}

\begin{abstract}
:
This study sought to establish the effect of economic determinants on the performance of dairy cooperative societies in Kericho County. Specifically, the study was to determine the performance trends of the societies and the extent to which economic determinants affect performance. The following economic determinants were examined; capital formation, competition, volatility of prices of milk, capacity utilisation, adoption of technology and entrepreneurship. The study adopted descriptive research design, using census of the entire population of 51 respondents comprising 36 members of management committees, 4 managers and 11 employees of 5 active dairy cooperative societies. Both primary and secondary data were collected for the purpose of the study. Primary data was collected using a questionnaire while secondary data was collected in a schedule. Data was analysed using descriptive statistics which included percentages. Data was presented by use of tables and charts. The findings indicated that the performance of dairy cooperative societies in Kericho County was on decline and were affected by economic determinants. Total turnover for three cooperative societies decreased from Kshs 9, 304,000 in 2008 to Kshs 2,970,000 in 2012, showing $68 \%$ decline. Average milk prices paid to members decreased from $80 \%$ to $64 \%$ of alternative channels prices in 2008 and 2012 respectively. Overall, the dominant economic determinant is capital formation which was considered by $85.7 \%$ of respondents to affect performance to a high extent; followed by entrepreneurship (67.4\%), capacity utilisation (67.3\%), adoption of technology (63.3\%), and competition (53.1\%). 38. $8 \%$ of the respondents considered volatility of milk prices affected performance to a low extent, $40.8 \%$ were neutral and $20.4 \%$ believed the effect was to a high extent. This study recommends the transformation of dairy cooperative societies in Kericho County from traditional agricultural producer marketing organisations to New Generation Cooperatives, which while preserving the cooperative principles such as one member one vote on policy issues and distribution of earnings according to patronage, focus on value, added processing activities. It is further recommended that dairy cooperative societies prepare and implement strategic and business plans to promote development, growth and performance in a dynamic economic environment faced with industrialization, globalisation and technological changes affecting business organisations. Further research can be done on social factors that affect performance of dairy cooperative societies in Kericho County.
\end{abstract}

\section{Keywords:}

ECONOMIC DETERMINANTS, PERFORMANCE, DAIRY COOPERATIVES

JEL Classification: M20 


\section{Introduction}

Ministry of Cooperative Development (2012) annual reports show that there were 33 registered dairy cooperative societies in Kericho but, only four were active. Of the four cooperatives, one resumed operations in 2012 after being dormant for 10 years. The cooperatives were under performing, with decline in turnover and lack of growth in membership, share capital, retained earnings and number of employees. Annual turnover for each of two active dairy cooperatives in Kericho declined over the past five years. The third cooperative society started operations in 2009 and achieved low turnover over two years and ceased dairy activity in 2012. The fourth dairy cooperative society was dormant since 2002 and resumed operations in 2012.

The current paper considers economic determinants of performance of dairy cooperatives to be capital formation or access to capital resources, competition, volatility of prices of milk, capacity utilization, adoption of technology and entrepreneurship.

\section{Cooperative societies in Kericho County}

As in other regions of Kenya, the number of producer marketing cooperatives in the county increased rapidly after independence, from 5 in 1963 to 87 in 1992 when the sector was liberalized. Producer cooperatives in Kericho County are in coffee, sugar cane and dairy sectors, involved in collection, storage and further transportation of produce to the buyers or their agents on behalf of the members. The cooperatives developed market opportunities for the produce and aimed to improve margins by negotiation of better prices for the produce.

\section{Statement of the problem}

Out of nineteen registered dairy cooperative societies in Kericho County, four were active, MOCD (2011). Turnover declined over the years and payouts for produce were below those which prevailed in other market channels. The societies were not able to procure and supply inputs to the members at competitive prices. Furthermore the cooperatives had not registered any growth over the past five years. The Ministry of Cooperative Development (2012) Annual report shows that turnover recorded by the dairy cooperatives in Kericho county in 2011 was kshs 4,194 million, compared to kshs 5,535 million in 2010 and Kshs 13,953 million in 2005, ( a 70\% decrease from 2005) The dairy cooperatives in Kericho County were at the lower end of value chain, collecting, bulking, chilling and selling of raw milk to processors while peer cooperative societies, Githunguri Dairy Farmers Cooperative Society and Ndumberi Dairy Cooperative Society in Kiambu had moved higher up the chain, processing and 
marketing added value milk products (pasteurized milk, yoghurt, cheese and ghee) offered to market under "FRESHA" and "WINNERS" brands respectively. Therefore; the study, sought to determine the performance trends and the effect of economic determinants on the performance of dairy cooperative societies in Kericho County.

\section{Objectives}

This paper attempts to establish the extent to which economic determinants affect performance of dairy cooperatives in Kericho County.

\section{Performance of dairy cooperative societies in Kericho County}

The dairy cooperative societies which were surveyed have been given code numbers in the tables and charts in order to preserve confidentiality of data obtained from official sources and records.

\section{Economic determinants that affect performance}

\section{Competition}

Dairy cooperative societies in Kericho faced strong competition in the marketing of milk with other participants in the dairy sector comprising processors, self help groups and informal traders. The informal traders, apart from offering higher prices than the cooperatives, also pay cash for milk purchased unlike the cooperatives which pay much later after they get paid by the processors. United States Agency for International Development (USAID) (2009) observes that marketing cooperatives are in competition with business and non business organisations for resources and markets.

Table: 1.1 Level of agreement that competition affected performance

\begin{tabular}{|l|r|r|r|}
\hline Level & \multicolumn{1}{|l|}{ Frequency } & \multicolumn{1}{|l|}{ Percent } & Cumulative Percent \\
\hline Strongly disagree & 1 & 2.0 & 2.0 \\
Disagree & 8 & 16.3 & 18.4 \\
Neutral & 0 & 0 & 18.4 \\
Agree & 29 & 59.2 & 77.6 \\
Strongly agree & 11 & 22.4 & 100.0 \\
Total & 49 & 100.0 & \\
\hline
\end{tabular}


The results in Table 1.1 indicate that there was agreement by $81.6 \%$ of the respondents agreed that competition had adversely affected the overall performance of their dairy cooperative societies. Dairy cooperative societies in Kericho faced strong competition from the processors, mainly Brookeside and Buzeki. The processors offer higher prices for and make regular and prompt payments on a monthly basis and have attracted many farmers away from the cooperatives to sign supply contracts.

$18.4 \%$ of the respondents did not agree that competition had adversely affected overall performance. This is consistent with a finding by Omore, et al (1999) that following liberalization of milk marketing in 1992, an increasing number of private sector participants were getting involved in transporting, processing and distribution of milk, most of which was sold raw and that milk traders operated mostly in high density peri-urban areas, particularly in Kiambu and Muranga districts where the competition they provided threatened the survival of some dairy cooperatives. In another study, Mudavadi, et al (2001), found that milk marketing in Western Kenya was mainly informal through hawking and milk bars and with liberalisation of milk marketing in 1992 and lifting of urban milk market monopoly previously enjoyed by KCC, there were few dairy farmers cooperative societies that existed in the region to market members milk after most collapsed or were on the verge of collapse.

Table: 1.2 Level of agreement that competition caused to loss of members

\begin{tabular}{|l|r|r|r|}
\hline Level & \multicolumn{1}{|l|}{ Frequency } & Percent & Cumulative Percent \\
\hline Strongly disagree & 0 & 0 & 0 \\
Disagree & 1 & 2.0 & 2.0 \\
Neutral & 0 & 0 & 0 \\
Agree & 28 & 57.1 & 59.2 \\
Strongly agree & 20 & 40.8 & 100.0 \\
Total & 49 & 100.0 & \\
\hline
\end{tabular}

Source: Field data (2016)

Table 1.2 indicates that about $98 \%$ of the respondents agreed that competition had caused loss of members by their cooperatives. The loss was caused by attraction of members to alternative market channels which offered higher prices for milk. In addition to higher prices for milk, informal milk traders made cash payments for milk on delivery and were preferred by farmers to the dairy cooperatives which paid for milk long after delivery. The decline in membership in dairy cooperative societies in Kericho is consistent with Wanyama, Develtere and Pollet (2008) observation that 
since membership in agricultural cooperatives was previously motivated by the desire to get access to the only marketing channel for produce, the availability of several market channels in the new era could significantly reduce cooperative membership as some members could opt to sell their produce to alternative buyers.

Table: 1.3 Level of agreement that competition led to decline in milk deliveries

\begin{tabular}{|l|r|r|r|}
\hline Level & Frequency & Percent & Cumulative Percent \\
\hline Strongly disagree & 0 & 0 & 0 \\
Disagree & 0 & 0 & 0 \\
Neutral & 0 & 0 & 59.2 \\
Agree & 29 & 59.2 & 100.0 \\
Strongly agree & 20 & 40.8 & \\
Total & 49 & 100.0 & \\
\hline
\end{tabular}

Source: Field data (2016)

The summary of results in Table 1.3 shows that all respondents (100\%) agreed that competition had caused decline of milk deliveries to their cooperatives by members. The decline has arisen from members opting to sell their milk to alternative market channels comprising informal traders and processors. The informal traders offered higher prices and mostly paid cash for milk delivered. The farmers with high volumes of milk preferred to sell to processors, mainly Brookeside Dairies and Buzeki because of higher prices than the cooperatives and prompt payments usually after the month end and conveniently by direct credits to the farmers' bank accounts.

Table: 1.4 Level of agreement that competition caused pressure for higher prices

\begin{tabular}{|l|r|r|r|}
\hline Level & Frequency & Percent & Cumulative Percent \\
\hline Strongly disagree & 0 & 0 & 0 \\
Disagree & 0 & 0 & 0 \\
Neutral & 0 & 0 & 0 \\
Agree & 24 & 49.0 & 49.0 \\
Strongly agree & 25 & 51.0 & 100.0 \\
Total & 49 & 100.0 & \\
\hline
\end{tabular}

Source: Field data (2016)

The results summarized in Table 1.4 shows agreement by all the respondents (100\%), that competition had put pressure on the dairy cooperatives to increase prices for milk delivered by members. Members have other market options for their milk and will maximize their revenues by selling to the outlets will paid higher prices and better services. To retain members the dairy cooperative societies, are striving to be at par with other players in terms of pricing and service delivery. 


\section{Volatility in prices of milk}

Dong, Du and Gould (2011) noted that the inherent characteristics of milk and its products make dairy markets vulnerable to price volatility, such as bulkiness, extreme perish ability, and inelastic demand, seasonal price variation induced by mismatched production and demand. Dairy cooperative societies in Kericho operate in a business environment affected fluctuations in milk for prices caused the effects of weather patterns on milk production.

\section{Table: 1.5 Level of agreement that volatility caused fluctuations of volumes}

\begin{tabular}{|l|r|r|r|}
\hline Level & Frequency & \multicolumn{1}{|c|}{ Percent } & Cumulative Percent \\
\hline Strongly disagree & 0 & 0 & 0 \\
Disagree & 0 & 0 & 0 \\
Neutral & 0 & 0 & 0 \\
Agree & 32 & 65.3 & 65.3 \\
Strongly agree & 17 & 34.7 & 100.0 \\
Total & 49 & 100.0 & \\
\hline
\end{tabular}

Source: Field data (2016)

The results summarized in Table 2.5 confirms that volatility of milk prices had resulted in irregular volumes of milk sold through their dairy cooperatives. The dairy cooperatives are affected by fluctuations in the prices for milk and when the processors especially NKCC drop prices, members divert their milk sales to alternative market channels which pay higher prices.

Table: 1.6 Level of agreement that volatility affected planning of operations

\begin{tabular}{|l|r|r|r|}
\hline Level & \multicolumn{1}{|c|}{ Frequency } & \multicolumn{1}{|c|}{ Percent } & Cumulative Percent \\
\hline Strongly disagree & 0 & 0 & 0 \\
Disagree & 3 & 6.1 & 6.1 \\
Neutral & 0 & 0 & 6.1 \\
Agree & 24 & 49.0 & 55.1 \\
Strongly agree & 22 & 44.9 & 100.0 \\
Total & 49 & 100.0 & \\
\hline
\end{tabular}

Source: Field data (2016)

The results showsn in Table 1.6 indicates that $93.9 \%$ of the respondents agreed that volatility of prices of milk had caused challenges in planning operations of their dairy cooperatives. $6.1 \%$ of the respondents did not agree that volatility of prices of milk affected planning in their dairy cooperative societies. 
Volatility of prices for milk is mainly caused by seasonal fluctuations in production so that prices for raw milk drop during a period of glut and increase during dry spells when demand out strips supply. Such fluctuations affect planning of operations by the dairy cooperatives in Kericho the same as Mburu, Wakhungu and Githu (2007) found from a study in Kiambu District, that the degree of volatility of prices for milk made it difficult to plan cash flow needs for the dairy enterprise and cash flow problems occur when milk prices fall below expected levels, USDA (2004), observes that high price volatility adds difficulties to dairy farms in both business and financial planning and directly increase the market risk.

Table: 1.7 Level of agreement that volatility of prices affected pay outs for milk

\begin{tabular}{|l|l|r|r|}
\hline Level & Frequency & Percent & Cumulative Percent \\
\hline Strongly disagree & 0 & 0 & 0 \\
Disagree & 1 & 2.0 & 2.0 \\
Neutral & 0 & 0 & 2.0 \\
Agree & 32 & 65.3 & 67.3 \\
Strongly agree & 16 & 32.7 & 100.0 \\
Total & 49 & 100.0 & 100.0 \\
\hline
\end{tabular}

Source: Field data (2016)

The summary of results in Table 1.7 shows that, $98 \%$ of the respondents agreed that volatility of prices of milk had put pressure on their dairy cooperative to make high pay outs for milk deliveries and $2 \%$ did not agree.

\section{Capital formation}

Capital formation (net capital accumulation) by business enterprises is necessary for working capital and capital investments for continued operation of the business (mandatory investment), replacement of existing parts when they break down or wear out and expansion investments that are expected to add substantially to revenue generation.

Table: 1.8 Level of agreement that capital formation was through bank loans

\begin{tabular}{|l|lr|l|lr|}
\hline Level & Frequency & & Percent & Cumulative Percent \\
\hline Strongly disagree & 2 & 4.1 & \\
Disagree & 16 & 32.7 & \\
Neutral & 0 & 0 & 36.7 \\
Agree & 21 & 42.9 & 36.7 \\
Strongly agree & 10 & & 20.4 & & 79.6 \\
Total & & & & 100.0 \\
& 49 & & 100.0 & & 100.0 \\
\hline
\end{tabular}

Source: Field data (2016) 
Table 1.8 results shows that $63.3 \%$ of the respondents agreed that capital formation in their cooperatives had been provided by banks through loans and advances. $36.8 \%$ of respondents did not agree that capital formation was through bank loans and advances.

Table: 1.9 Level of agreement that capital formation was for Investment in Equipment

\begin{tabular}{|l|l|r|r|}
\hline Level & Frequency & Percent & Cumulative Percent \\
\hline Strongly disagree & 0 & 0 & 0 \\
Disagree & 4 & 8.2 & 8.2 \\
Neutral & 0 & 0 & 8.2 \\
Agree & 40 & 81.6 & 89.8 \\
Strongly Agree & 5 & 10.2 & 100.0 \\
Total & 49 & 100.0 & 100.0 \\
\hline
\end{tabular}

Source: Field data (2016)

The results in Table 1.9 shows that $91,8 \%$ of respondents agreed that capital formation in their dairy cooperatives had been used to invest in equipment for milk transport. 8.2\% of respondents did not agree that capital formation had been used to purchase vehicles for milk transport.

Pischke (1995) found that several dairy cooperative societies have been revived by the donation of vehicles by foreign donors, similar to Geuze (2011) observation that Nyala Multipurpose Cooperative Society received a grant to purchase a tractor for milk transportation.

Table: 1.10 Level of agreement that capital formation affects performance

\begin{tabular}{|l|r|r|r|}
\hline Level & Frequency & \multicolumn{1}{|c|}{ Percent } & Cumulative Percent \\
\hline Strongly disagree & 0 & 0 & 0 \\
Disagree & 0 & 0 & 0 \\
Neutral & 0 & 0 & 0 \\
Agree & 33 & 67.3 & 67.3 \\
Strongly Agree & 16 & 32.7 & 100.0 \\
Total & 49 & 100.0 & \\
\hline
\end{tabular}

Source: Field data (2016)

Results summarized in Table 1.10 shows that $100 \%$ of the respondents agreed that capital formation affected performance dairy cooperative society. Capital accumulation in the dairy cooperatives in Kericho was through share capital, surplus and retention of earnings. Share capital contributions were low and members were reluctant to increase their share capital because no additional rights or benefits accrued from share capital increases. Capital formation through surplus and retention of earnings was also low 
because of poor financial performance. The dairy cooperatives had achieved total surplus of only Kshs 2.1 million in five years between 2008 and 2012. The dairy cooperative societies in Kericho do not have access to adequate capital resources to support investments in replacement of assets and more importantly for expansion and growth of their business.

Capital constraints affect progress of dairy cooperatives in the value chain and restrict them to marketing of unprocessed milk thus inhibiting their growth performance. Only one cooperative had a chilling plant, albeit very old and received milk from members and bulked for delivery to the processors and operates at $42 \%$ of the installed capacity. The other cooperatives were involved in simple milk collection and delivery to the processors. Two of the cooperatives had purchased vehicles for milk transport using bank loan financing.

Expansion projects such as milk processing plant require significant capital resources.

Rouse and Pischke (1997) observed that capital for the operation and improvement of cooperative business can came from three main sources: directly from members themselves ( one-time or annual membership fees, member contributions with no individual ownership attached, such as service fees, member share capital, individual member deposits with the cooperative which may be used for the business, deferred payment to members for part of the produce delivered to the cooperative), funds created through the retention of cooperative business surpluses, external sources of funds to run operations or to finance investments ( grants, short term loans, long term loans and trade credits offered by suppliers).

According to Geuze (2011), Nyala Dairy Multi-purpose Cooperative Society, took a Kshs 8 million loans from the Cooperative Bank, borrowed Kshs 3 million from its own SACCO and Ksh 1 million from its contractor to buy land and start building a new dairy plant.

Oikocredit collaboration report, (2007), indicates that the construction of processing plant building for Githunguri Dairy Farmers' Cooperative Society was funded by members' savings over 13 years while the equipment was financed by Oikocredit loan of Kshs 70 million. Milk processing capability led to rapid growth of the dairy cooperative between 2003 and 2007 with daily milk intake increasing from 30,000 litres to 120,000 litres per day.

\section{Capacity utilization}

Dairy cooperative societies in Kericho were formed with their core functions being those of marketing cooperatives which include marketing of members' milk, providing services 
such as procurement of farm inputs and credits to members against check of on milk deliveries. To perform the functions, the cooperatives have acquired vehicles, milk collection cans, coolers stores and shops. The cooperative societies will derive benefits of economies of scale through full utilisation of the resources.

\section{Table: 1.11 Level of agreement that low utilization adversely affected performance}

\begin{tabular}{|l|r|r|r|}
\hline Level & Frequency & \multicolumn{1}{|c|}{ Percent } & \multicolumn{2}{c|}{ Cumulative Percent } \\
\hline Strongly disagree & 1 & 2.0 & 2.0 \\
Disagree & 2 & 4.1 & 6.1 \\
Neutral & 9 & 18.4 & 24.5 \\
Agree & 27 & 55.1 & 79.6 \\
Strongly agree & 10 & 20.4 & 100.0 \\
Total & 49 & 100.0 & \\
\hline
\end{tabular}

Source: Field data (2016)

Table 1.11 shows that $75.5 \%$ of the respondents agreed that low capacity utilization of resources/facilities had adversely affected performance of their cooperatives. $18.4 \%$ of the respondents were neutral while $6.1 \%$ did not agree that low capacity utilization affected performance of their cooperatives adversely.

Low utilization of vehicles in the transportation of milk was commonplace with cases of $20 \%$ of the load capacity utilized as a result of decline in the volumes of milk delivered by members. A similar situation was found with respect to aluminum milk cans which were used to collect and deliver milk to either the bulking hubs or the processors. Only $20 \%$ of the cans were in use and the rest $80 \%$ were idle and wasting away. One cooperative had a chilling plant which was found to be grossly underutilized. The installed daily capacity was 1,200 litres of milk but the average daily milk intake was 500 litres, a $42 \%$ capacity utilisation. Stores had remained empty over long periods due to inability to procure input supplies for members and were in general poor state of repair.

Low capacity utilization of resources in the cooperatives resulted in higher costs from failure to achieve economies of scale as in the case of milk transport vehicles and chilling plants. Other costs were incurred in the maintenance and upkeep of idle equipment in addition to wastages and pilferages. Limo and Popoi (2011), reported that in Western Province, most of the milk coolers were underutilized and some were never used at all, broken down and vandalized. 


\section{Adoption of technology}

Adoption of technology by cooperative societies is vital in the present business environment in which competitive advantage can be realised by efficient processes through technological advances.

In the case of dairy cooperatives which deal in highly perishable product the extent adoption of technology in the whole supply chain from collection, quality preservation, handling, cooling methods, bulking and marketing is critical to performance.

Efficient communication systems and access to market information and emerging trends provide competitive edge. Computerised data processing and record keeping enhance availability of information for management control and decision making.

Table: 1.12 Level of agreement that technology had not been adopted by cooperatives

\begin{tabular}{|l|r|r|r|}
\hline Level & Frequency & Percent & \multicolumn{1}{c|}{ Cumulative Percent } \\
\hline Strongly disagree & 2 & 4.1 & 4.1 \\
Disagree & 15 & 30.6 & 34.7 \\
Neutral & 0 & 0 & 34.7 \\
Agree & 22 & 44.9 & 79.6 \\
Strongly agree & 10 & 20.4 & 100.0 \\
Total & 49 & 100.0 & \\
\hline
\end{tabular}

Source: Field data (2016)

The summary of results in Table 1.12 shows that $65.3 \%$ of respondents agreed that technology had not been adopted in any area of operation in their cooperatives. $34.7 \%$ of the respondents did not agree that technology had not been adopted in their cooperatives.

Only one dairy cooperative society had adopted e-mail communication. The status in Kericho is similar to the finding of Mureithi (2013), that most dairy cooperatives in Kabete, Kiambu County, do not have trained and motivated employees to use modern ICT. 
Table: 1.13 Level of agreement that technology will improve efficiency and productivity

\begin{tabular}{|l|r|r|r|}
\hline Level & Frequency & \multicolumn{1}{|c|}{ Percent } & \multicolumn{2}{c|}{ Cumulative Percent } \\
\hline Strongly disagree & 3 & 6.1 & 6.1 \\
Disagree & 15 & 30.6 & 36.7 \\
Neutral & 0 & 0 & 36.7 \\
Agree & 25 & 51.0 & 87.8 \\
Strongly agree & 6 & 12.2 & 100.0 \\
Total & 49 & 100.0 & \\
\hline
\end{tabular}

Source: Field data (2016)

The summary of results in Table 1.13 shows that $63.2 \%$ of the respondents agreed that adoption of technology will improve efficiency and productivity in their dairy cooperatives. $36.8 \%$ of the respondents did not agree that adoption of technology will improve efficiency and productivity. This is consistent with Veerbeek and Kithinji (2011) observation that he operations of Tulaga Cooperative Society are managed through a computerized system which enabled them to keep up to date records and monitor operations including milk collection, deliveries, rejections, stores operations and members records.

\section{Entrepreneurship}

The performance of dairy cooperatives is affected by the leadership competencies and the management skills which form entrepreneurship capacity of the organisations. Leadership with vision and dynamism is required to develop and operationalise strategic plans to achieve sustainable growth and viability of the cooperatives.

Table: 1.14 Level of agreement that earnings were maximized

\begin{tabular}{|l|r|r|r|}
\hline Level & \multicolumn{1}{|c|}{ Frequency } & \multicolumn{1}{|c|}{ Percent } & Cumulative Percent \\
\hline Strongly disagree & & & \\
Disagree & 30 & 61.2 & 61.2 \\
Neutral & & & \\
Agree & 19 & 38.8 & 100.0 \\
Strongly agree & 49 & 100.0 & 100.0 \\
Total & & & \\
\hline
\end{tabular}

Source: Field data (2016)

The summary of results shows in Table 1.14 indicates that $61.2 \%$ of the respondents did not agree that management committees strive to maximize earnings in their dairy cooperatives while $38.8 \%$ agreed that management committees of their dairy cooperatives strive to maximize earnings. USAID (2009) notes that decisions made in 
most farmer groups are ad hoc and often lead to activities that were not economically viable.

Table: 1.15 Level of agreement that the cooperative had a strategic plan

\begin{tabular}{|l|r|r|r|}
\hline Level & \multicolumn{1}{|c|}{ Frequency } & Percent & Cumulative Percent \\
\hline Strongly disagree & 16 & 32.6 & 32.6 \\
Disagree & 19 & 38.8 & 71.4 \\
Neutral & 0 & 0 & 71.4 \\
Agree & 9 & 18.4 & 89.8 \\
Strongly agree & 5 & 10.2 & 100.0 \\
Total & 49 & 100.0 & \\
\hline
\end{tabular}

Source: Field data (2016)

The results summarized in Table 1.15 shows that $71.4 \%$ of the respondents did not agree that a strategic plan had been prepared for their dairy cooperatives while $28.6 \%$ of the respondents agreed. This is consistent with USAID (2009) finding that most farmer groups in Kericho milk shed are ill-equipped to prepare and operationalize strategic and business plans.

Table: 1.16 Level of agreement that entrepreneurship affected performance

\begin{tabular}{|l|r|r|r|}
\hline Level & Frequency & \multicolumn{1}{|c|}{ Percent } & \multicolumn{2}{c|}{ Cumulative Percent } \\
\hline Strongly disagree & 3 & 6.1 & 6.1 \\
Disagree & 9 & 18.4 & 24.5 \\
Neutral & 9 & 18.4 & 42.9 \\
Agree & 14 & 28.6 & 71.4 \\
Strongly agree & 14 & 28.6 & 100.0 \\
Total & 49 & 100.0 & \\
\hline
\end{tabular}

Source: Field data (2016)

The summary of results in Table1.16 shows that $56.8 \%$ of the respondents agreed that entrepreneurship had adversely affected performance of their cooperatives while $24.5 \%$ of respondents did not agree and $18.4 \%$ maintained a neutral opinion.

Niekerk (1988) reported that cooperative failures in the former homelands of South Africa were due mainly to lack of management experience and knowledge, lack of capital resources, and disloyalty of members due to ignorance.

Omiti (2002) noted that the major obstacles affecting dairy cooperatives relate to illiteracy of most farmers, the low level of educational and professional qualifications, and the lack of group dynamic skills among managers. Leadership of dairy cooperative societies in Kericho was predominantly by farmers most of whom had basic appreciation of 
cooperative management. The management committee members lacked the necessary skills in cooperative management, vision and dynamism required to strengthen and transform the societies to sustainable business enterprises.

Entrepreneurship competencies affected performance and the manner in which the resources were harnessed to maximize earnings and benefits to the members.

The management committees of the dairy cooperatives were found not to strive to maximise earnings. Entrepreneurial approach to the planning for the growth and financial viability of the cooperatives by increased productivity and competitiveness was lacking particularly the ability to detect opportunities and strategically plan how to benefit from them. There were no strategic plans underpinned by vision and mission statements to define the long term goals and objectives of the cooperatives. Performance was adversely affected by lack of curiosity, creative thinking, business orientation and boldness to explore opportunities, new ideas and approaches to grow the dairy cooperative through the value chain to process and market value added milk and milk products.

\section{Conclusions and recommendations}

Overall the most important economic determinant of performance is capital formation which was considered by $85.7 \%$ of respondents to affect performance to a high extent; followed by entrepreneurship (67.4\%), capacity utilisation $(67.3 \%)$, adoption of technology $(63.3 \%)$, and competition (53.1\%). $38.8 \%$ of the respondents considered volatility of milk prices affected performance to a low extent, $40.8 \%$ were neutral and $20.4 \%$ considered volatility of prices to affect performance to a high extent.

In order to improve the performance of dairy cooperative societies in Kericho County, this study recommends the transformation of dairy cooperatives in Kericho from traditional agricultural marketing cooperative societies to New Generation Cooperatives, which, while preserving the cooperative character, with the principle of one-member one-vote on important policy issues and distribution of earnings according to patronage, focus on added value activities with member capital contributions linked to product delivery rights which attain value and can be transferred within restricted or closed membership.

It is further recommended that the cooperatives prepare and implement strategic plans to promote structured and focused decisions and actions to achieve development, growth and enhanced performance in dynamic economic environment characterized by technological changes, industrialization, liberalisation and globalisation affecting business enterprises. The key strategic thrusts should include capital formation which is the most important economic determinant of performance. Other critical strategic thrusts required 
for the cooperatives are; development of entrepreneurship, capacity utilisation, adoption of technology and competition.

\section{Areas for future research}

Further research can be done on the social factors affecting performance of dairy cooperatives in Kericho County. It is also suggested that a study is carried out on political determinants of performance dairy cooperative societies. A comparative study of dairy cooperative societies based on economic determinants can also be done.

\section{References}

Alchian, A. and Demsetz, H. (1972). "Production, information costs, and economic organisation" American Economic Review Vol. 62 (5):777-795

Barton, D. (2000). What is a cooperative? Unpublished paper, Kansas State University, USA

Bogstrom, M.H. (2008). Situation and development for agricultural cooperatives in Europe. Lecture delivered on the occasion of the IRU-Law seminar, Berlin, $25^{\text {th }}$ November,2003.

Chaddad, F.R. and Cook, M.L. (2004). Understanding new cooperative models: An ownership control rights typology. Review of Agricultural Economics, Vol. 26, No. 3, pp. 1249-1253

Cook M L. (1995). The future of US agricultural cooperatives: A neo-institutional approach. American journal of Agricultural Economics Vol. 77 (5):1153-1159

Delgado, C, Nicholson, C. and Staal, S.(1997). Smallholder Dairy under Transaction Costs in East Africa, World Development, Vol. 25, No. 5, pp. 779-794.

Develtere, P. (1994). Cooperation and Development, ACCO, Leuven,

Develtere, P. Pollet, I. Wanyama. F. (2007), "Co-operating out of poverty, the renaissance of the African cooperative movement," Rap Spider web, Oldham.

Dong, F., Du, X.,Gould, B.W(2011). Milk price volatility and its determinants, Agricultural and Applied Economics Association, 2011 Annual Meeting, July 24-26, Pittsburgh, Pennsylvania

East Africa Dairy Development Program (2008). The Dairy Value Chain In Kenya, A report by Technoserve Kenya.

Fulton, J. R Popp, M. P. and Gray, C. (1996). Strategic alliances and joint venture agreements in grain marketing cooperatives, Journal of Cooperatives.Vol. 11, pp 1-14. 
Geuze, R. (2011), Prospection and Business Plan Analysis of Dairy Cooperatives in Kenya, Agriterra

Helmberger, P.G. and Hoos, S, (1962). Cooperative enterprise and organisation theory, Journal of farm economics Vol. 44:275-290

Holloway, G. Nicholson, C. Delgado, C. Stall, S. and Ehui, S.(2000). Agroindustrialisation through institutional innovation: Transaction costs, cooperatives and milk-market development in east-African Highlands, Agricultural Economics, Vol. 23, Issue No. 3, pp.279-288.

Igual, J., and Elena, J. F.M (2008).Social Economy and the Cooperative Movement in Europe: Contribution to a New Vision of Agriculture and Rural Development in Europe of 27. CIRIEC Espana. Special issue No.62 pp 147-172 